\title{
PEMANFAATAN SEKAM PADI DALAM PEMBUATAN BRIKET SEKAM SEBAGAI ALTERNATIF PENGGANTI MINYAK TANAH
}

\section{THE USE OF RICE HUSK FOR HUSK BRIQUETTE AS AN ALTERNATIVE SUBSTITUTION TO KEROSENE}

\author{
Oleh: \\ Efratenta Katherina Depari, Saprinurdin, dan Deselina \\ Jurusan Kehutanan Fakultas Pertanian Universitas Bengkulu \\ Email:efra_tenta@yahoo.com, saprinurdin2000@yahoo.com, deselina@ymail.com
}

\begin{abstract}
The purpose of the community service activity is to obtain alternative fuel, reduce waste rice husk, rice husk value-added so that it becomes more useful and reduce the illegal logging. This community service activity is done from August - September 2014 in the village of Srikaton, District of Pondok Kelapa, Central Bengkulu. The target of this activity is PKK members, members of the youth institution and farmer group members. The methods used in this activities are counseling, training and demonstration. Rice husk briquette as an alternative kerosene in the village Srikaton is one right step in the processing of agricultural waste. Rice husk briquette is also one way that can be used by housewives, especially to save money in the purchase of fuel for cooking needs.
\end{abstract}

Keywords: rice husk, rice husk briquette, kerosene, Srikaton

\section{PENDAHULUAN}

Pada beberapa tahun belakangan ini kelangkaan akan bahan bahar minyak (BBM) terutama minyak tanah terjadi di hampir seluruh wilayah Republik Indonesia. Salah satu faktor penyebab kelangkaan tersebut adalah meningkatnya kebutuhan energi (BBM) di Indonesia yang mencapai 215 juta liter/hari tidak seimbang dengan produksi dalam negeri (178 juta liter/hari) (Listiyanawati et al, 2008). Pertumbuhan konsumsi energi naik sebesar $\pm 7 \%$ per tahun, sejalan dengan pertumbuhan ekonomi $(6,3 \%)$ serta pertumbuhan penduduk (Sagala, 2000). Harga minyak tanah yang telah menjadi tombak hidup masyarakat melambung tinggi dan semakin tidak terjangkau karena jauh di atas harga eceran tertinggi. Hal ini sangat memprihatinkan mengingat minyak tanah sangat dibutuhkan oleh sebagian besar rumah tangga di Indonesia terutama masyarakat kelas bawah sebagai bahan bakar minyak untuk memasak. Pemakaian gas LPG sebagai bahan bakar masih terbatas jumlahnya karena masyarakat mesti membeli kompor dan tabung gas yang harganya relatif mahal.

Keadaan ini tidak dapat dibiarkan berlarut-larut karena dapat memicu gejolak sosial di masyarakat. Salah satunya yang terjadi hutan menjadi terancam karena untuk kebutuhan hidupnya akan bahan bakar penduduk melakukan penebangan hutan untuk dijadikan kayu bakar. Untuk itu perlu dicari alternatif lain sebagai pengganti bahan bakar minyak tanah 
sehingga kegiatan memasak yang merupakan kegiatan vital tetap berjalan dan keberadaan hutan dapat terselamatkan. Salah satu upaya mengatasi ketergantungan terhadap pemakaian bahan bakar minyak ialah melalui bahan bakar alternatif, seperti briket.

Briket adalah padatan yang umumnya berasal dari limbah pertanian. Sifat fisik briket tidak kompak, tidak keras dan tidak padat seperti sekam tanpa melewati proses pembakaran (pengarangan). Briket sekam merupakan salah satu briket biomassa karena berasal dari bahan organik (lignoselulosa). Penggunaan briket biomassa sebagai pengganti minyak tanah dapat menyelamatkan $\mathrm{CO}_{2}$ sebanyak 3,5 juta ton untuk Indonesia dan untuk dunia 6,07 x 109 ton $\mathrm{CO}_{2}$ per tahun (Pari, 2002).

Sekam padi adalah salah satu sumber energi biomasa yang dipandang penting untuk menanggulangi krisis energi belakangan ini khususnya di daerah pedesaan. Ketersediaan sekam padi di hampir 75 negara di dunia diperkirakan sekitar 100 juta ton dengan energi potensil berkisar $1,2 \times 10^{9}$ (GJ/tahun dan mempunyai nilai kalor rata-rata $15 \mathrm{MJ} / \mathrm{kg}$ ). Indonesia sebagai negara agragris mempunyai sekitar 60.000 mesin penggiling padi yang tersebar di seluruh daerah dengan kisaran produksi sekam padi 15 juta ton per tahun. Untuk kapasitas besar beberapa mesin penggiling padi mampu memproduksi 10-20 ton sekam padi per hari (Winaya, 2008).

Sekam padi merupakan hasil sampingan dari proses penggilingan gabah menjadi beras. Pada proses penggilingan padi dapat menghasilkan beras giling sebanyak $65 \%$ dan limbah hasil gilingan sebanyak 35\% yang terdiri dari sekam 25\%, dedak dan bekatul sebanyak 10\% (Yudono et al., 1996). Sekam padi merupakan limbah pertanian yang belum banyak dimanfaatkan oleh petani dan penduduk pedesaan. Rendahnya kandungan hara pada sekam padi di satu pihak dan tingginya kadar lignin di lain pihak mengakibatkan sekam padi ini tidak dapat digunakan sebagai sumber hara di dalam tanah namun berperan sebagai kondisioner sifat fisik tanah.

Adanya limbah dimaksud menimbulkan masalah penanganannya yang selama ini dibiarkan membusuk, ditumpuk dan dibakar yang semuanya berdampak negatif terhadap lingkungan sehingga penangulangannya perlu dipikirkan. Salah satu jalan yang dapat ditempuh adalah memanfaatkannya menjadi produk yang bernilai tambah dengan teknologi aplikatif dan kerakyatan sehingga hasilnya mudah disosialisasikan kepada masyarakat Penggunaan sekam padi sebagai bahan baku briket sekam merupakan salah satu upaya penanggulangan limbah pertanian dan memberi manfaat lain yaitu dapat mengurangi ketergantungan terhadap bahan bakar minyak.

Desa Srikaton yang terletak di Kecamatan Pondok Kelapa Kabupaten Bengkulu Tengah merupakan salah satu daerah penghasil beras. Rata-rata penduduknya bermata pencarian sebagai petani tradisional. Taraf hidup yang masih rendah merupakan ciri umum dari kehidupan para petani karena panen tidak dapat dilakukan setiap saat. Pendapatan di luar hasil panen padi sangat membantu berlangsungnya kehidupan keluarga petani.

Pembuatan briket sekam sebagai sumber energi alternatif pengganti minyak tanah maupun kayu bakar dapat mengurangi pengeluaran rumah tangga petani. Selain itu briket sekam tersebut dapat dijual untuk menambah pendapatan keluarga petani. Hal lain yang juga penting adalah terselamatnya keberadaan hutan kita yang pada saat ini mulai terancam keberadaanya. 
Beberapa tahun belakangan harga bahan bakar minyak terutama minyak tanah menduduki harga tertinggi dengan harga di tingkat pengecer Rp 10.000 - Rp 12.000 . Minyak tanah merupakan salah satu sumber energi panas yang paling banyak digunakan oleh penduduk Indonesia terutama yang tinggal di pedesaan. Minyak tanah menjadi kebutuhan yang sangat vital salah satunya dibutuhkan untuk memasak. Salah satu usaha yang dilakukan penduduk untuk mendapatkan sumber energi lain adalah dengan melakukan penebangan pohon di hutan yang akan dijadikan bahan bakar. Hal ini tentu akan menambah rusaknya hutan tropis di negara kita yang keadaannya semakin terancam oleh aktivitas manusia yang tidak bertanggung jawab.

Tujuan dari kegiatan pengabdian ini adalah (1) Mendapatkan alternatif pengganti bahan bakar minyak, (2) Mengurangi limbah sekam padi, (3) Memberikan nilai tambah sekam padi sehingga menjadi lebih bermanfaat, dan (4) Mengurangi pengambilan kayu dari hutan/illegal logging. Sedangkan manfaat yang diharapakn dengan adanya kegiatan ini adalah menambah pengetahuan para kelompok tani dalam mengelola limbah pertanian, menciptakan lapangan kerja baru bagi anggota kelompok tani sehingga menambah pendapatkan para kelompok tani, kelompok tani memiliki alternatif pengganti bahan bakar minyak /energi baru, mengurangi pemakaian bahan bakar minyak/gas, serta diharapkan dapat meningkatkan kesejahteraan keluarga petani.

\section{METODE PENGABDIAN}

\section{Tempat, Waktu Kegiatan, dan Khalayak Sasaran}

Kegiatan pengabdian pada masyarakat dilakukan pada Bulan Agustus - September 2014 di Desa Srikaton Kecamatan Pondok Kelapa Kabupaten Bengkulu Tengah. Sasaran dari kegiatan ini adalah karang taruna, para anggota kelompok tani dan anggota kelompok PKK di Desa Srikaton.

\section{Metode Penerapan IPTEK}

Transformasi teknologi yang efektif bagi masyarakat berpendidikan rendah adalah menggunakan metode penyuluhan, pelatihan dengan banyak membuat demonstrasi atau melakukan praktek langsung diiringi pendampingan (White, 1990). Oleh karena itu dalam kegiatan penerapan IPTEKS digunakan metode: Penyuluhan dan tatap muka: mengenai pentingnya menjaga kelestarian hutan dan pemanfaatan limbah lingkungan; Pelatihan: pengetahuan cara membuat briket sekam padi; dan Demonstrasi: pembuatan briket sekam padi.

\section{HASIL DAN PEMBAHASAN}

Kegiatan pengabdian pada masyarakat ini dilaksanakan Bulan Agustus-September 2014. Kegiatan lapangan diawali dengan sosialisasi kegiatan yaitu dengan mendatangi Kepala Desa Srikaton Bapak M. Sarjoni Sandi, anggota kelompok PKK dan anggota 
kelompok tani untuk menjelaskan tujuan diadakannya kegiatan pengabdian ini. Berdasarkan hasil interview diketahui bahwa para anggota Kelompok PKK dan Kelompok Tani di Desa Srikaton belum pernah mendapatkan informasi dan mempraktekkan penanganan limbah sekam padi sebagai bahan pembuatan briket sekam untuk alternatif pengganti minyak tanah.

Kegiatan pengabdian dilakukan dengan metode penyuluhan dan demonstrasi yang dilakukan di kediaman Bapak Kepala Desa Srikaton. Kegiatan dihadiri oleh anggota Karang Taruna, ibu-ibu Kelompok PKK dan para Kelompok Tani Desa Srikaton.

Secara umum pelaksanaan kegiatan pengabdian Ipteks bagi masyarakat berjalan lancar. Penyuluhan dilakukan untuk menyampaikan pengetahuan mengenai pentingnya pengelolaan limbah, pemanfaatan limbah lingkungan dan mengenai cara pemasaran produk limbah. Kegiatan pembuatan briket sekam padi sangat menarik perhatian peserta kegiatan pengabdian Dosen Muda dikarenakan cara pembuatan yang sangat mudah dengan memanfaatkan limbah yang ada di sekitar rumah seperti serasah daun-daun kering, sekam padi dan serbuk gergaji. Sementara itu alat untuk membuat briket sekam padi ini cukup menggunakan bamboo yang banyak tumbuh di Desa Srikaton. Pemakaian bambu ini menggantikan pipa PVC.

Sekam padi adalah salah satu sumber energi biomasa yang dipandang penting untuk menanggulangi krisis energi belakangan ini khususnya di daerah pedesaan. Ketersediaan sekam padi di hampir 75 negara di dunia diperkirakan sekitar 100 juta ton dengan energi potensil berkisar $1.2 \times 10^{9}(\mathrm{GJ} /$ tahun dan mempunyai nilai kalor rata-rata $15 \mathrm{MJ} / \mathrm{kg}$. Indonesia sebagai negara agragris mempunyai sekitar 60.000 mesin penggiling padi yang tersebar di seluruh daerah dengan kisaran produksi sekam padi 15 juta ton per tahun. Untuk kapasitas besar beberapa mesin penggiling padi mampu memproduksi 10-20 ton sekam padi per hari (Winaya, 2008).

Selanjutnya Winaya (2008) menjelaskan bahwa sifat dan karakteristik sekam padi meliputi berat jenis yang kecil sekitar $122 \mathrm{~kg} / \mathrm{m}^{3}$, jumlah abu hasil pembakaran yang tinggi dengan temperatur titik lebur abu yang rendah. Abu hasil pembakaran berkisar antara 16$23 \%$ dengan kandungan silika sebesar 95\%. Kandungan uap air (moisture) pada sekam padi relatif sedikit karena sekam padi merupakan kulit kulit padi yang yang kering sisa proses penggilingan. Sekam padi mempunyai panjang sekitar 8-10 mm dengan lebar 2-3 $\mathrm{mm}$ dan tebal $0.2 \mathrm{~mm}$. Karakteristik lain yang dimiliki bahan bakar sekam padi adalah kandungan zat volatil yang tinggi yaitu berkisar $60-80 \%$ sedangkan bahan bakar fosil hanya mempunyai 20-30\% untuk jenis batu bara medium.

Briket adalah padatan yang umumnya berasal dari limbah pertanian. Sifat fisik briket tidak kompak, tidak keras, dan tidak padat, seperti sekam dan serbuk gergaji tanpa melewati proses pembakaran (pengarangan). Dalam aplikasi produk ada beragam jenis briket, yaitu briket arang selasah, briket sekam padi atau serbuk gergaji, dan briket kotoran sapi. Setiap jenis briket memiliki keunggulan dan kelemahan masing-masing (Tim Penulis PS, 2008).

Briket sekam sebagai salah satu eko briket memiliki karakteristik bahan sebagai berikut: kadar air 9.12\%, kadar volatile solid (VS) 78.79, kadar fixed carbon (FC) 5.84 dan 
kadar abu 6.25. Sedangkan nilai kalor sekam padi adalah 3225.6 (Listiyanawati et al.,, 2008).

Briket sekam padi dibuat dengan menambahkan lem kanji cair ke dalam sekam padi dan bahan serasah campuran yang sudah kering. Lem ini berfungsi untuk merekatkan bahan sehingga bisa dicetak menjadi briket (Tim Penulis PS, 2008). Briket yang sudah dicetak dikeringkan pada sinar matahari agar tidak menimbulkan jamur ketika disimpan. Pengeringan di bawah sinar matahari menghasilkan penyebaran panas ke dalam bahan berlangsung secara bertahap dan menyeluruh sehingga penyerapan air ke udara lebih merata, sementara pengeringan dengan oven tidak demikian halnya (Harsono, 2002).

Briket sekam padi memiliki keuntungan mudah dibuat, murah, mudah penggunaannya, praktis dan relatif aman digunakan. Namun briket sekam padi ini memiliki beberapa kekurangan yaitu mengeluarkan asap sehingga lebih baik digunakan di ruangan terbuka, tidak dapat dimatikan dengan cepat, pijar api tidak mudah terlihat (walaupun panas sekali).

Saat ini beberapa produk daur ulang hasil pengolahan limbah seperti briket, kompos, pupuk cair, media tanam, pakan ternak, batako dan biogas telah memberikan hasil yang dapat dibanggakan dan mudah diaplikasikan. Produk tersebut cukup mendapat tempat di masyarakat dan telah diperjualbeikan secara komersial. Dari sisi finansial keuntungan yang diperoleh cukup menggiurkan dan mampu meningkatkan kesejahteraan pengolahnya. Peluang usaha produk berbahan baku limbah sangat terbuka lebar dengan berbahai harapan menjanjikan di masa depan.

Dampak negatif sampah atau limbah mungkin tidak bisa dihilangkan secara tuntas sampai ke akarnya. Namun usaha pengelolaan dan pengolahan limbah yang telah dilakukan berbagai pihak turut memberikan kontribusi guna menanggulangi problematika limbah. Kerja keras pemerintah tentu tidak akan berjalan mulus tanpa partisipasi dan respon langsung masyarakat. Salah satu peran nyata masyarakat bisa tersalurkan melalui penggunaan produk berbahan baku limbah maupun hasil daur ulangnya di kehidupan sehari-hari.

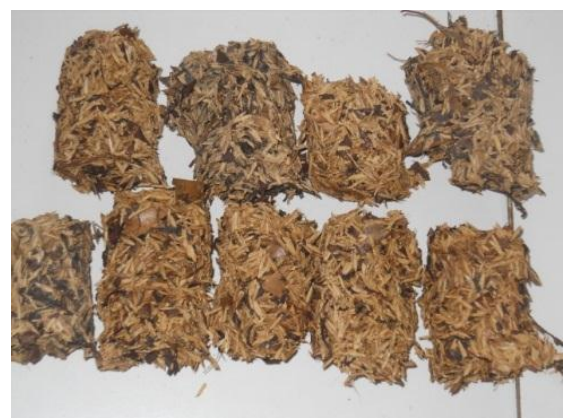

Gambar 1. Briket Sekam Padi yang Siap Palai

KESIMPULAN DAN SARAN

\section{Kesimpulan}

Pembuatan briket sekam padi sebagai alternatif pengganti bahan bakar minyak di Desa Srikaton merupakan salah satu langkah yang tepat dalam mengolah limbah pertanian. 
Pembuatan briket sekam padi ini juga merupakan salah satu cara yang dapat dipakai oleh ibu rumah tangga khususnya untuk menghemat pengeluaran dalam membeli bahan bakar untuk kebutuhan memasak.

\section{Saran}

Untuk kegiatan pengabdian yang akan datang disarankan agar penandatanganan kontrak pengabdian dan pencairan dana dilakukan tepat waktu sehingga kegiatan pengabdian dapat dilakukan dengan baik.

\section{DAFTAR PUSTAKA}

Harsono, H., 2002, Pembuatan Silika Amorf dari Limbah Sekam Padi, Jurnal Ilmu Dasar, Volume 3(2): 98-103.

Listiyanawati, D., Y. Trihadiningrum, D. Sungkono, D.A., Mardhiani, P. Christiyanto, 2008, Eko-Briket dari Komposit Sampah Plastik Campuran dan Lignoselulosa, Prosiding Seminar Nasional Manajemen Teknologi VII, Surabaya.

Pari, G., 2002, Teknologi Alternatif Pemanfaatan Limbah industri dan Pengolahan Kayu, Makalah Falsafah Sains, Program Pasca Sarjana/S3 IPB.

Sagala, F. P., 2000, Peran Energi dalam Pembangunan Nasional Memasuki Milenium III, Widyanuklida, Vol. 3(1): 1-5.

Tim Penulis PS., 2008, Penanganan dan Pengolahan Sampah, Penebar Swadaya, Jakarta.

White, B., 1990, Agro-Industri, Industrialisasi Pedesaan dan Trasformasi Pedesaan, Makalah disampaikan pada rangkaian diskusi ke-100 pada Pusat Pengembangan Ilmu-ilmu Sosial (PPIS) Universitas Brawijaya, 27 Januari 1990, Malang.

Winaya, I.N.S., 2008, Prospek Energi dari Sekam Padi dengan Teknologi Fluidized Bed Combustion, Inovasi Online, Vol.11/XX/Juli 2008 http://io.ppi-jepang.org/article. php?id. 20/02/2009.

Yudono, B., F. Oesman dan Hermansyah, 1996, Komposisi Asam Lemak Sekam dan Dedak Padi. Buletin Nutrisi dan Makanan Ternak, Vol 32(2): 8-11. 